\title{
DAMPAK PENDAYAGUNAAN INFAQ PRODUKTIF TERHADAP PENINGKATAN PENDAPATAN PADA MUSTAHIQ YDSF (YAYASAN DANA SOSIAL AL-FALAH) DI KEDIRI
}

\author{
Chandra Ari Haryanto \\ Mahasiswa Program Studi S1 Ekonomi Islam - Fakultas Ekonomi dan Bisnis-Universitas \\ Airlangga \\ Email : canaverend@gmail.com \\ Nisful Laila \\ Departemen Ekonomi Syariah - Fakultas Ekonomi dan Bisnis - Universitas Airlangga \\ Email : nisful.laila@gmail.com
}

\begin{abstract}
:
The impact of infaq productive utilization of the increased income on mustahiq YDSF (Foundation of Social Funds Al-Falah) in Kediri. The goal of this research is to know the impact of utilization of infaq productive done by mustahiq to increase revenues.

The research method used is a qualitative approach, strategy case studies and analysis techniques, descriptive data collection is done through interviews and observations of the informants. Informants were participants KUM (Independent Business Group) in Kediri composed of 8 people who have attended this program and get help infaq in the from the board LAZ YDSF (the foundation of social funds al-falah) through KUM.

Resulth from this study that the productive utilization of infaq by mustahiq through KUM (Independent business group) in the form of venture capital has an impact on income growth mustahiq. Can be seen that the eight mustahiq interviewed seven mustahiq who experienced improvement, where as only one mustahiq whose income is not increasing.
\end{abstract}

Key word : impact utilization, infaq productive, income mustahiq.

\section{PENDAHULUAN}

\section{A. Latar Belakang}

Kemiskinan yang terjadi di negaranegara berkembang seperti halnya di Indonesia diakibatkan oleh tidak meratanya pendapatan dari sektor riil yang diterima oleh masyarakat. Seperti tidak berimbangnya pemerataan pendapatan di negara maju dengan negara berkembang. Penyebab terbesar dari tingkat kemiskinan yang tinggi di negara berkembang adalah besarnya jumlah penduduk. Sehingga, dapat dilihat bahwa jika negara dengan jumlah penduduk yang banyak maka hasil dari pertumbuhan ekonomi di negara tersebut akan dibagi secara merata dan hasilnya akan sedikit sekali. Negara maju lebih banyak mendapat keuntungan dari hasil pertumbuhan ekonomi dunia. Sedangkan, pada negara berkembang hasil yang diperoleh sangat sedikit sehingga tidak dapat secara maksimal meningkatkan kesejahteraan (Sumber: www.bps.go.id diakses pada 20-08-2014).

Secara garis besar faktor yang mempengaruhi tinggi rendahnya kemiskinan adalah tingkat pendapatan dan kesenjangan dalam pendapatan. Meskipun suatu negara memiliki tingkat pendapatan nasional per kapita yang tinggi, tetapi bila distribusi pendapatan 
nasional tidak merata maka tingkat kemiskinan suatu negara akan tetap tinggi.

Masih banyak kemiskinan yang terjadi terutama di Indonesia ini merupakan indikasi bahwa negara Indonesia masih belum bisa mensejahterakaan rakyatnya secara merata padahal tugas negara adalah menjamin rakyat miskin dan anak-anak terlantar sesuai yang tercantum dalam pasal 34 ayat (1) UUD 1945.

Berdasarkan badan pusat statistik menunjukan adanya penurunan presentase kemiskinan pada setiap tahun, tetapi angka ini diangkap tinggi dikarenakan 28 juta atau sekitar 11,37\% masyarakat indonesia masih hidup di bawah garis kemiskinan. Dibutuhkan adanya penanganan dan solusi yang serius dari pemerintah untuk mengatasi kemiskinan salah satu solusi yang tepat adalah zakat dan infaq.

Menurut Hafidhuddin (2002: 91-93) salah satu sebab belum berfungsinya zakat secara optimal sebagai pemerataan pendapatan dan belum optimalnya zakat yang terkumpul kepada lembaga-lembaga pengumpul zakat, karena pengetahuan masyarakat terhadap harta yang dikeluarkan zakatnya masih sangat kurang dan hanya terbatas pada sumber-sumber yang sifanya masih konvensional yang secara jelas dinyatakan dalam Al-Quran dan hadits dengan persyaratan tertentu. Salah satu pembahasan yang penting tentang fiqih zakat adalah menentukan sumber- sumber zakat yang wajib dikeluarkan zakatnya apalagi bila dikaitkan dengan kegiatan ekonomi yang terus berkembang dari waktu ke waktu. Al-Qur'an dan Hadits secara jelas menyebutkan beberapa jenis harta yang wajib dizakati, seperti perak, emas, hasil tanam, buah-buahan, barang dagangan, hewan ternak dan barang temuan.

Di samping dapat mendekatkan diri dengan Allah, zakat juga dapat menjembatani dan mempererat hubungan antara sesama manusia yang dalam perinsipnya Islam sering disebut sebagai agama yang menjunjung tinggi persaudaraan, saling membantu dan tolong menolong. Dalam segala hal manusia selalu dihadapkan pada kenyataan adanya umat kaya dan umat miskin, baik di negara maju maupun negara terbelakang atau juga dalam negara yang sedang berkembang. Semua sudah didasarkan pada ketentuan yang sudah ditetapkan oleh Allah melebihkann sebagian kamu dari yang lain dalam hal rizki (Q.S. 16:71).

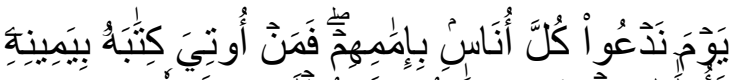

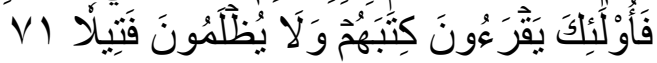
Wa Allāhu Fađđala Ba`đakum `Alá Ba`đin FıAr-Rizqi. Famā Al-Ladhīna Fuđđillū Birāddī Rizqihim `Alá Mā Malakat 'Aymānuhum Fahum.

Fihi Sawā'un 'Afabini'mati AlLahi Yajĥadūna.

"(Ingatlah) suatu hari (yang di hari itu) Kami panggil tiap umat dengan pemimpinnya; dan barangsiapa yang diberikan kitab amalannya di tangan 
kanannya maka mereka ini akan membaca kitabnya itu, dan mereka tidak dianiaya sedikitpun".

Menurut Mufraini (2012 : 194) kelompok amil zakat akan lebih optimal jika diperankan oleh intermediary system (badan amil zakat dan lembaga amil zakat). Dengan demikian tingkat optimalisasi dari zakat tersebut akan lebih optimal jika dapat dimelihat bahwa amil sebagai lembaga dan amil sebagai orang keduanya yang mewakili seseorang sebagai khalifah di muka bumi agar selalu memanfaatkan harta dengan sebaikbaiknya. Konsep amil dalam kajian fiqih adalah orang atau lembaga yang mendapat tugas untuk mengambil dan menerima zakat dari para muzakki serta menjaga dan memeliharanya kemudian menyalurkanya ke mustahiq yang berhak menerimanya. Dengan syarat amil zakat sudah akil baliq (mukallaf), memahami hukum zakat dengan baik, jujur, amanah, memiliki kemampuan untuk melaksanakan tugas keamilan.

Secara konsep tugas-tugas amil yang pertama, melakukan pendataan muzakki dan mustahiq, melakukan pembinaan, menagih, mengumpulkan dan menerima zakat, mendoakan muzakki saat menyerahkan zakat kemudian menyusun penyelengaraan sistem administratif dan manajerial dana zakat yang terkumpul tersebut. Kedua, memanfaatkan data terkumpul mengenai peta mustahiq dan muzakki zakat, memetakan jumlah kebutuhannya dan menentukan kiat distribusinya. Pembinaan berlanjut untuk mustahiq yang menerima dana zakat. UU No. 23 tahun 2011 dinyatakan tentang pengelolaan zakat dengan keputusan menteri agama (KMA) dan keputusan jendral bimbingan masyarakat dan urusan haji tahun 2011 tentang pedoman teknis pengelolaan zakat Bab I pasal 1 ayat 1.

Undang-Undang nomor 23 tahun 2011 tentang zakat, yaitu Bab I tentang pengumpulan zakat, pasal 1 ayat (1) dan ayat (2) dikemukakan secara eksplisit tentang harta yang termasuk dalam objek zakat. Dengan dikeluarkannya beberapa Undang-Undang tersebut menyiratkan tentang perlunya BAZ dan LAZ meningkatkan kinerja sehingga menjadi amil zakat yang profesional, amanah terpercaya dan memiliki program kerja yang jelas dan terencana, sehingga mampu mengelola zakat, baik pengembaliannya maupun pendistribusiannya dengan terarah yang kesemuanya itu dapat meningkatkan kualitas hidup dan kehidupan para mustahiq.

Antonio (1999: 34) menjelaskan pendayagunaan yang ada pada masa sekarang telah diatur dalam undangundang sesuai dengan aturan yang ada pada syariah berdasarkan dengan 8 asnaf yang telah ditentukan yaitu fakir, miskin, amil, muallaf, riqab, garim, shabilillah, dan ibnussabil. Sebagaimana dijelaskan dalam surat at-Taubah: 60. 


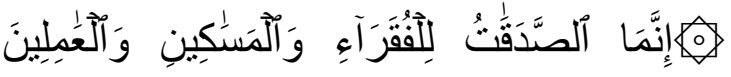

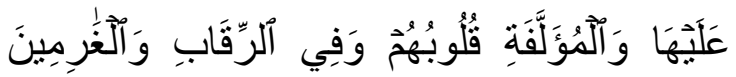

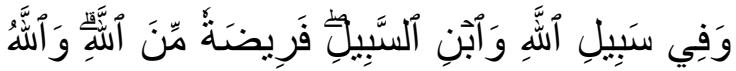

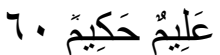
'Innamā Aş-Şadaqātu Lilfuqarā'i Wa AlMasākinni Wa Al- 'Āmilina 'Alayhā Wa AlMu'vallafati Qulūbuhum Wa FI Ar-Riqābi WaAl-Ghārimina Wa Fl Sabili AlLahi Wa Aibni As-Sabili Farīđatan Mina AlLahi Wa Allāhu `AlimunĤakimun.

"Sesungguhnya zakat-zakat itu, hanyalah untuk orang-orang fakir, orang-orang miskin, pengurus-pengurus zakat, para mu'allaf yang dibujuk hatinya, untuk (memerdekakan) budak, orang-orang yang berhutang, untuk jalan Allah dan untuk mereka yuang sedang dalam perjalanan, sebagai suatu ketetapan yang diwajibkan Allah, dan Allah Maha Mengetahui lagi Maha Bijaksana".

Pengelolaan zakat di Indonesia sekarang sudah diserahkan kepada Lembaga Zakat yang sudah ditunjuk termasuk BAZ dan LAZ yang bertanggung jawab kepada pemerintah sesuai tingkatanya. Dalam pengelolaannya zakat yang diberikan kepada delapan golongan yang telah ditetapkan dalam Al-Qur'an, jika dimanfaatkan semaksimal mungkin zakat dapat mensejahterakan para mustahiq. Sehingga, bagi para lembaga yang ditunjuk diharapkan tidak hanya mendistribusikan zakat yang sifanya konsumtif berupa uang dan makanan, tetapi bentuk pendistribusian dana tersebut berupa modal usaha yang biasa disebut dengan zakat produktif yang diharapkan mampu memaksimalkan zakat yang diberikan kepada mustahiq untuk dikelola dengan baik sebagai bentuk untuk meningkatkan pendapatan mustahiq secara terus-menerus tidak hanya sekali pakai seperti zakat konsumtif. Sehingga, kedepanya mustahia dapat juga bertransformasi menjadi muzakki dengan ini sangat efektif zakat produktif digunakaan untuk mengentaskan kemiskinan yang telah ada. Dengan pendapatan mustahiq yang selalu meningkat secara terus menerus juga dapat meningkatkan kesejahteraan mustahiq secara umum.

\section{LANDASAN TEORI}

\section{A. Definisi Zakat}

Menurut Hafidhuddin (2002:7) kata zakat mempunyai beberapa arti yaitu albarakatu 'keberkahan', al-namaa 'pertumbuhan dan perkembangan', aththaharatun 'kesucian', dan ash-shalahu 'kebebasan'. Sedangkan secara istilah, zakat adalah bagian dari harta dengan persyaratan tertentu, yang Allah SWT mewajibkan kepada pemiliknya untuk diserahkan kepada yang berhak menerimanya dengan syarta-syarat tertentu. Hubungan antara pengertian zakat menurut bahasa dengan pengertian menurut istilah sangat nyata dan erat sekali, yaitu bahwa harta yang dikeluarkan zakatnya akan menjadi berkah, tumbuh, berkembang dan bertambah serta suci dan baik. 


\section{B. ZIS untuk kegiatan Produktif}

Permono

(1995:

mengungkapkan zakat dibedakan menjadi dua yaitu : zakat konsumtif dan zakat produktif. Zakat konsumtif adalah zakat yang diberikan kepada mustahia untuk dikonsumsi langsung tanpa ada perkembangan terus menerus. Sedangkan, zakat produktif adalah zakat yang diberikan kepada mustahiq dalam berbagai bentuk yang berbeda sehingga zakat tersebut dapat dikembangkan kembali, bentuk tersebut antara lain :

1. Beasiswa

Beasiswa merupakan bantuan kepada orang yang kurang mampu yang ditujukan pada bidang pendidikan. Zakat ini diberikan langsung pada mustahiq untuk digunakan biaya pendidikan sekolah.

2. Modal

Zakat modal merupakan bantuan yang diberikan kepada mustahiq dalam bentuk uang dan faktor produksi untuk meningkatkan usaha. Modal yang bersifat faktor produksi cenderung berbentuk alat-alat yang depat mendukung usaha atau pekerjaan mustahiq. Sedangkan, modal uang adalah sejumlah dana yang diberikan kepada mustahiq untuk dapat digunakan sebagai modal usaha yang akan didirikan untuk meningkatkan taraf hidup.

3. Pelatihan

Dalam hal ini pelatihan lebih cenderung pada upaya bagaimana meningkatkan kemampuan seseorang terutama mustahia untuk dapat mengelola dana zakat yang telah diberikan dengan baik agar tidak siasia.

4. Pendampingan

Dalam pemberian dana zakat produktif selalu disertakan pendampingan terhadap mustahiq, ini dikarenakan pemberian dana mustahiq harus selalu dimanfaatkan sesuai yang telah diharapkan sebelumnya agar dana tersebut selalu berkembang.

\section{Definisi Infaq}

Hasan (2008: 11) Perintah mencari harta telah diperintahkan dalam AlQur'an, meskipun tidak secara langsung. Perintah berzakat dan berinfaq untuk muzakki ini bertujuan supaya setiap muslim berusaha menjadi hartawan. Apabila seseorang tidak mampu dalam berzakat, tapi sekurang-kurangnya seseorang dapat berinfaq.

Semua sudah dijelaskan dalam AlQur'an bahwa shalat dan zakat dirangkaikan pada delapan puluh dua tempat. Hal ini berarti, hubungan vertikal (dengan Allah) dan horizontal (dengan sesama manusia) harus berjalan saling bersamaan jangan sampai mengabaikan salah satunya.

Di antara ayat-ayat yang berhubungan dengan perintah shalat dan zakat ialah :

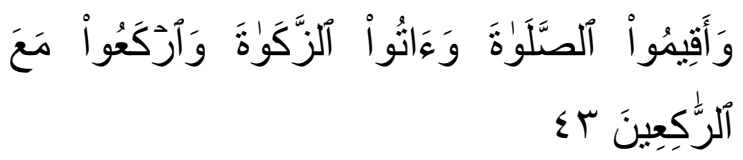


Wa 'Aqīmū Aş-Şalāata Wa 'Ātū Az-Zakāata WaArka 'ù Ma`a Ar-Rāki īna.

"Dan dirikanlah shalat, tunaikanlah zakat dan ruku'lah beserta orang-orang yang rukun". (al-Baqarah/2: 43).

Kemudian yang berhubungan dengan infaq pun Allah memerintahkan dalam Al-Quran, di antaranya :

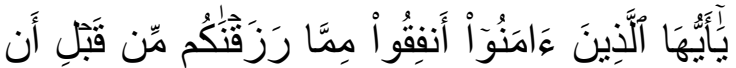

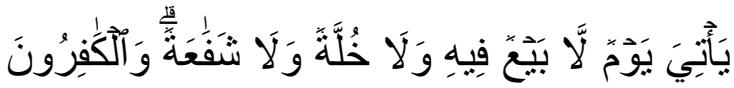

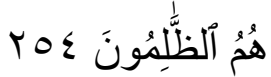

Yā 'Ayyuhā Al-Ladhina 'Āmanū 'Anfiqū Mimma Razaqnākum Min Qabli 'An Ya'tiya Yawmun Lā Bay un Fihi Wa Lā Khullatun Wa Lā Shafā 'atunWa AlKāfirūna Humu Až-Žālimūna.

"Hai orang-orang yang beriman, belanjakanlah (di jalan Allah) sebagian dari rezeki yang telah Kami berikan kepadamu sebelum datang hari yang pada hari itu tidak ada lagi jual beli dan tidak ada lagi syafa'at. Dan orang-orang kafir itulah orang-orang yang zalim". (alBaqarah/2: 254)

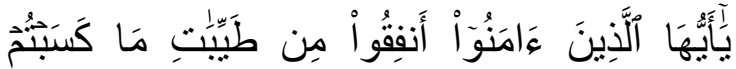

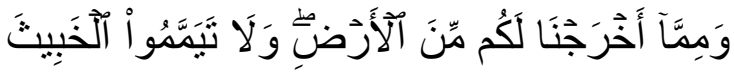

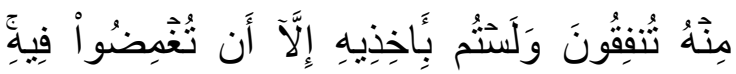

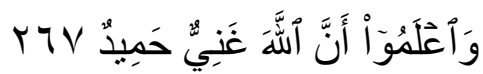

Yā 'Ayyuhā Al-Ladhīna

'Āmanū 'Anfiqū MinTayyibāti Mā Kasabtum Wa Mimmā 'Akhrajnā Lakum Mina Al-'Arđi Wa Lā Tayammamū Al-Khabītha Minhu Tunfiqūna Wa Lastum Bi'ākhidhīhi 'Illā 'An Tughmiđū
Fihi Wa A 'lamū'Anna Al-Laha Ghanīyun Hamìdun.

"Hai orang-orang yang beriman, nafkahkanlah (di jalan allah) sebagian dari hasil usahamu yang baik-baik dan sebagian dari apa yang Kami kelvarkan dari bumi untuk kamu. Dan janganlah kamu memilih yang buruk-buruk lalu kamu menafkahkan daripadanya, padahal kamu sendiri tidak mau mengambilnya melainkan dengan memincingkan mata terhadapnya. Dan ketahuilah, bahwa Allah Maha Kaya lagi Maha Terpuji". (alBaqarah/2: 26).

Semua ayat-ayat yang telah disebutkan di atas memerintahkan supaya kita berzakat dan berinfaq. Perintah itu baru dapat kita laksanakan sesudah memiliki harta benda atau kekayaan. Tuntutan yang paling tinggi adalah menunaikan zakat dan yang paling rendah adalah menunaikan infaq.

Menurut Hasan (2008: 13) zakat memiliki ketentuan khusus, sedangkan infaq tidak. Besar kecilnya sangat bergantung kepada keadaan keuangan dan keikhlasan memberi dan yang terpenting adalah hak orang lain yang ada di dalamnya sudah kita keluarkan.

Kedudukan setiap orang tidaklah sama. Ada yang mendapat karunia Allah lebih banyak, ada yang sedikit, dan bahkan ada yang untuk makan sehari-hari pun susah mendapatkannya.

Kesenjangan yang terjadi ini perlu didekatkan dan sebagai salah satu caranya adalah dengan berinfaq. Orang 
yang memiliki lebih banyak harta berkewajiban mendekatkan kesenjangan yang terjadi, karena memang selalu ada hak dalam harta orang kaya.

\section{Pengelolaan Zakat}

Pengelolaan zakat merupakan kegiatan dalam bentuk perencanaan, pelaksanaan, dan pengordinasian dalam pengumpulan, pendistribusian, dan pendayagunaan zakat.

1) Penghimpunan Zakat

Dalam penghimpunan dana zakat lembaga zakat dapat melakukan empat tahapan, Muhammad (2011: 96) menyatakan terdapat empat tahapan dalam penghimpunan dana zakat oleh lembaga zakat yaitu :

1. Menentukan segmen dan target muzakki

2. Menetapkan strategi untuk penghimpunan

3. Membangun sistem komunikasi

4. Actuating (menyusun dan melakukan pelayanan)

2) Pendistribusian Zakat

Undang-undang No.23 Tahun 2011 tentang pengelolaan zakat, Bab III tentang pengumpulan, pendistribusian, pendayagunaan dan pelaporan bagian pendistribusian pasal 25 dan 26 menyatakan zakat wajib didistribusikan kepada mustahiq sesuai dengan syariat Islam dan dilakukan dengan skala prioritas berdasarkan prinsip pemerataan, keadilan, dan kewilayahan.

3) Pendayagunaan Zakat
Berdasarkan UU No. 23 Tahun 2011 tentang pengelolaan zakat, Bab III tentang pendayagunaan zakat pada pasal 27 menyatakan bahwa zakat dapat didayagunakan untuk usaha yang sifatnya produktif dalam rangka sebagai penanganan fakir miskin dan peningkatan kualitas umat. Pendayagunaan zakat untuk usaha produktif dilakukan apabila kebutuhan dasar mustahiq telah terpenuhi dengan tepat. Ketentuan lebih lanjut tentang pendayagunaan zakat untuk usaha produktif telah diatur dengan peraturan menteri.

Sistem pengelolaan harta oleh Lembaga Amil Zakat diarahkan kepada sasaran dalam pengertian yang sifanya lebih luas secara tepat guna, efektif, dan efisien serta dengan pendayagunaan harta zakat serbagunandan produktif. Dimana harta yang terkumpul tidak semuanya dibagikan pada zakat yang sifatnya konsumtif, akan tetapi ada sbagian yang diinvestasikan dalam hal yang sifatnya produktif dan nanti keuntungan dari pengelolaan dana zakat tersebut dapat dibagikan kepada golongan ekonomi yang lemah dalam bentuk modal usaha atau dana zakat. Hal ini dilakukan untuk memelihara dari bahaya investasi akibat pendistribusian zakat yang kurang bermanfaat dan zakat untuk kepentingan konsumtif yang tinggi. Dapat disimpulkan bahwa zakat merupakan instrumen untuk mempersempit kesenjangan ekonomi yang tinggi, meskipun zakat tersebut sifanya konsumtif maupun produktif. 


\section{E. Konsep Pendayagunaan Zakat}

Menurut Mufraini (2012 : 153-154) dana zakat pada awalnya lebih di dominasi pola pendayagunaan yang sifatnya secara konsumtif dengan pelaksanaan yang lebih maju saat ini zakat mulai dikembangkan dengan cara produktif. Sebagaimana yang telah dijelaskan pemanfaatan zakat dikategorikan menjadi empat macam, yaitu:

1. Pendayagunaan Konsumtif Tradisional Zakat dibagikan kepada mustahiq untuk dimanfaatkan secara langsung, seperti zakat fitrah yang diberikan kepada fakir miskin untuk memenuhi kebutuhan sehari-hari atau zakat maal yang dibagikan kepada korban yang sedang tertimpa kesusahan, seperti bencana alam.

2. Pendayagunaan Konsumtif Kreatif Konsumtif keratif ini merupakan jenis zakat yang diwujudkan dalam bentuk lainnya yang kadang berwujud barang, seperti diberikan dalam bentuk alat-alat sekolah atau beasiwa.

3. Pendayagunaan Produktif Tradisional Zakat yang merupakan bentuk dari barang-barang yang diberikan berupa kambing, sapi, alat cukur, dan lainnya yang sifatnya berupa zakat produktif. Pemberian dalam bentuk ini akan dapat meciptakan suatu usaha yang membuka lapangan kerja bagi fakir miskin.

4. Pendayagunaan Produktif Kreatif
Zakat yang diwujudkan dalam bentuk permodalan baik untuk membangun sesuatu yang sifatnya sosial atau menambah modal pengusaha kecil dalam kelangsungan usahanya.

Pendayagunaan berasal dari kata daya dan guna yang kemudian diberikan awalan pe dan akhiran an, menurut kamus besar bahasa Indonesia (KBBI, 2002: 242) menjelaskan bahwa kata daya berarti manfaat, sehingga dapat diartikan bahwa pendayagunaan merupakan pengusahaan atau berusaha agar mampu mendatangkan hasil dan manfaat dengan baik. Dengan kata lain juga dapat dijelaskan bahwa pendayagunaan yaitu memaksimalkan kegunaan atau peningkatan kegunaan.

\section{F. Konsep Pendapatan menurut Ekonomi} Islam

Dalam bukunya Qardhawi (2007: 458) mengungkapkan ekonomi Islam memandang pendapatan merupakan hasil yang diperoleh dari melakukan setiap usaha, baik berupa vang, barang, bahkan hasil yang lainnya. Hasil dari pendapatan dibedakan menjadi dua macam. Pertama, Penghasilan atau pendapatan yang diperoleh dari pekerja yang telah dikerjakan sendiri tanpa bergantung pada orang lain, berkat kecerdasan dan kecakapan merupakan penghasilan secara profesional. Kedua, penghasilan atau pendapatan yang diperoleh dari pekerjaan yang dikerjakan seseorang oleh pihak lain, baik perorangan, perusahaan dan pemerintah 
dengan memperoleh upah dan gaji yang telah diberikan sebagai hasil dari usaha.

Bantuan modal kerja yang diberikan kepada para mustahia bertujuan untuk memulai atau mengembangkan usaha mereka, sehingga pendapatan dari hasil usaha (pendapatan kotor) mustahiq dapat meningkat. Proses penyaluran dana dari pihak YDSF melalui program Kelompok Usaha Mandiri (KUM) dilakukan dengan mempertimbangkan beberapa kriteria. Bantuan modal kerja yang diperoleh melalui program KUM juga dapat memotivasi mustahia sebagai anggota program yang tadinya hanya bersetatus sebagai ibu rumah tangga untuk ikut serta mencari sumber penghasilan kelvarga. Sehingga, keaktifan mustahiq untuk bekerja tersebut akan berpengaruh positif terhadap tingkat pendapatan mustahiq.

\section{G. Proposisi}

Proporsi penelitian ini adalah pendayagunaan dana Infaq produktif dapat meningkatkan pendapatan mustahiq.

\section{METODE PENELITIAN}

\section{A. Pendekatan Penelitian}

Dalam suatu penelitian, pendekatan Penelitian sangat penting untuk menentukan arah dari suatu penelitian, dalam penelitian ini penulis menggunankan pendekatan metode kualitatif deskriptif. Penelitian ini dilaksanakan untuk menjawab rumusan masalah yaitu bagaimana dampak pendayagunaan zakat dan infaq produktif terhadap tingkat pendapatan mustahiq. Rumusan masalah itu tidak dapat diperoleh menggunakan perhitungan data dalam menemukan jawaban. Sehingga, untuk memperoleh jawaban tersebut harus menggunakan pendekatan kualitatif. Menurut (Sugiyono, 2011:9) Metode penelitian kualitatif adalah metode penelitian yang berlandaskan pada sifat postpositivisme, digunakan untuk meneliti pada kondisi obyek yang alamiah. Metode yang digunakan dalam penelitian ini adalah studi kasus deskriptif yang bertujuan untuk menjelaskan dan menggambarkan dampak dari pendayagunaan zakat dan infaq produktif terhadap peningkatan kesejahteraan pendapatan mustahiq.

Komponen desain penelitian untuk studi kasus menurut Yin (2009:29) ada lima yaitu, pertanyaan penelitian, proposisi, unit analisis, logika yang mengaitkan data dengan proposisi tersebut, dan kriteria untuk menginterpretasi temuan. Komponen-komponen desain penelitian untuk studi kasus menurut Yin (2008:29), yaitu:

1. Pernyataan peneliti merupakan Perumusan dari masalah yang menggunakan pertanyaan "bagaimana" yang sesuai dengan definisi yang diberikan Yin bahwa studi kasus adalah strategi yang cocok digunakan dalam penelitian yang pokok pertanyaannya menggunakan how dan why serta fenomena dalam konteks kehidupan nyata. 
2. Pada proposisi suatu penelitian mengerahkan perhatian peneliti kepada sesuatu yang harus diselidiki dalam ruang lingkup studinya. Prposisinya juga digunakan sebagai batasan suatu penyempitan data relevan. Proposisi pada penelitian ini adalah pendayagunaan zakat dan infaq produktif untuk pemberdayaan ekonomi mustahiq berdampak pada pengingkatan pendapatan mustahiq.

3. Unit-unit analisis merupakan komponen fundamental berkaitan dengan masalah penentuan kasus dalam penelitian yang bersangkutan. Kepustakaan terdahulu dapat menjadi tuntunan dalam menetapkan kasus dan unit analisis. Penentuan kasus dan unit analisis perlu meperhatikan peranan kepustakaan penelitian yang tersedia.

4. Logika yang mengaitkan data dengan proposisi yang disebut merupakan komponen mengetengahkan tahaptahap analisis data dalam penelitian studi kasus. Pengaitan data terhadap proposisi dapat dilakukan dengan banyak cara, namun tidak ada satu pun yang dapat terdefinisi secara pasti.

5. Kriteria untuk menginterpretasikan temuan merupakan komponen yang terakhir ini juga tidak memiliki satupun cara yang tepat yang dapat digunakan untuk menyusun kriteria guna menginterpretasikan tipe-tipe data temuan.

Alasan peneliti menggunakan strategi studi kasus adalah; pertama, strategi studi kasus memungkinkan hasil penelitian sulit untuk dimanipulasi karena peneliti memiliki kesulitan serta sedikit peluang untuk mengontrol peristiwaperistiwa yang akan terjadi. Kejadian yang dimaksud peneliti dalam penelitian ini adalah penentuan sampel titik pemberdayaan yang telah dilakukan. Kedua, studi kasus merupakan strategi yang sesuai dengan tipe pertanyaan penelitian ini. Ketiga, fokus penelitian ini terletak pada pendayagunaan zakat dan infaq produktif oleh mustahiq.

\section{B. Ruang Lingkup Penelitian}

Ruang lingkup penelitian adalah terkait dengan rumusan masalah dalam penelitian ini. Rumusan masalah dalam penelitian ini mengenai bagaimana dampak pendayagunaan infaq produktif terhadap peningkatan pendapatan mustahia pada Lembaga Amil Zakat YDSF Surabaya. Penelitian ini terbatas pada sampel kelompok mustahiq yang berlokasi di Kediri. Informan kelompok mustahiq tersebut mengatakan bagaimana dampak dari sistem pendayagunaan yang dilakukan oleh Lembaga Amil Zakat tersebut dapat meningkatkan pendapatan mustahiq. Ukuran indikator yang telah ditentukan, sehingga dapat dicari sampel tersebut untuk diteliti lebih dalam untuk mengetahui peningkatan pendapatan mustahiq dan penentuan tersebut diperoleh dari data lapangan.

Lembaga Amil Zakat yang menjadi objek penelitian ini adalah Lembaga Amil Zakat YDSF Surabaya yang terletak di jalan 
Kertajaya VIII C/ 17 Surabaya. Di pilinnya Lembaga Amil Zakat tersebut karena oleh peneliti dianggap memiliki informasi yang dalam dan seusai dengan maksud dan tujuan penelitian, sehingga mampu menjawab rumusan masalah yang dicari peneliti.

\section{Jenis dan Sumber Data}

Skripsi ini mengunakan 2 jenis data yaitu data sekunder dan data primer. Data sekunder adalah data yang diperoleh dari berbagai sumber yang telah ada. Data sekunder dapat diperoleh dari berbagai sumber seperti buku, jurnal, laporan, dan lain-lain. Data primer adalah data empiris yang diperoleh atau dikumpulkan oleh peneliti secara langsung dari informan dengan menggunakan daftar pertanyaan dan wawancara langsung sehingga dapat memudahkan peneliti untuk menganalisis masalah.

Sumber dan jenis data diperoleh dengan cara sebagai berikut:

a. Informan kunci

Informan kunci dalam penelitian ini yang dijadikan sebagai sumber data adalah mustahiq pada Lembaga Amil Zakat YDSF Surabaya yang berada di wilayah Kediri. Pemilihan kriteria informan mustahiq dipilih berdasarkan dari kelancaran mustahiq dalam membayar anggsuran dan kesanggupan mustahiq dalam berinfaq.

b. Data Penunjang

Data penunjang dalam penelitian ini merupakan data sekunder. Data sekunder adalah data yang diperoleh dan dikumpulkan melalui penelusuran studi dokumen yang terdapat pada tempat penelitian serta memiliki hubungan dengan permasalahan yang sedang diteliti.

\section{Prosedur Pengumpulan Data}

Teknik pengumpulan data merupakan langkah yang paling strategis dalam suatu penelitian, karena dapat dilihat tujuan utama dari penelitian adalah mendapatkan data. Tanpa mengetahui teknik pengumpulan data yang memenuhi standar data yang sudah ditetapkan (Sugiyono, 2012:224 ). Bila dilihat dari sumber datanya, pengumpulan data dapat mengunakan 2 cara yaitu mengunakan data primer dan data sekunder. Data primer adalah data yang langsung memberikan data pada pengumpul data (Sugiyono, 2012:225). Langkah-langkah memperoleh data primer sebagai berikut :

1. Persiapan awal

Pada tahap ini, penulis mengurus surat ijin penelitian skripsi secara formal kepada Fakultass Ekonomi dan Bisnis Universitas Airlangga sebagai kelengkapan dalam mengumpulkan data dari lembaga-lembaga yang relevan sebagai acuan pertama. Kemudian membuat kesepakatan untuk diijinkan meneliti objek untuk melakukan wawancara secara langsung dengan memberikan maksud dari wawancara dan penelitian.

2. Proses memasuki lokasi dan wawancara objek penelitian 
Peneliti mengumpulkan data dengan metode tanya jawab secara langsung dan mendalam pada objek penelitian. Pertanyaan dapat berkembang sesuai dengan perkembangan topik wawancara asalkan tetap berada dalam ruang lingkup penelitian. Waktu pelaksanaan wawancara tergantung pada kesepakatan yang telah dibuat.

3. Proses pengumpulan data

Pada tahap ini, peneliti mengumpulkan data dengan metode yang diperlukan, yaitu wawancara. Peneliti saat melakukan wawancara kepada objek penelitian akan mencatat dan merekam semua informasi yang diketahui dari objek penelitian tersebut yang kemudian hasil wawancara tersebut akan diinterpresikan sehingga dapat dijadikan hasil pembahasan dan simpulan dalam penelitian ini.

\section{E. Teknik Analisis}

Analisis data dalam penelitian kualitatif yang ada dalam (sugiyono, 2012:246) berdasarkan data yang dikembangkan Miles dan Huberman mengemukakan bahwa aktivitas dalam analisis data kualitatif dilakukan secara interaktif dan berlagsung secara terusmenerus sampai tuntas, sehingga data sudah jenuh. Aktivitas analisis data yang dimaksud yaitu reduksi data, penyajian data dan verifikasi.

1. Reduksi data

Data yang diperoleh dari lapangan yang jumlahnya cukup banyak yang harus dicatat secara teliti dan terperinci. Mereduksi data merupakan proses merangkum, memilih hal-hal yang pokok, memfokuskan pada hal-hal yang penting, dicari tema dan polanya.

2. Penyajian data

Langkah selanjutnya adalah penyajian data yang dilakukan dalam penelitian kualitatif penyajian data bisa dilakukan dalam bentuk uraian, bagan, hubungan antara kategori dan sejenisnya. Dalam penelitian kualitatif yang paling sering digunakan untuk menyajikan data dalam penelitian ini dengan bentuk teks yang bersifat naratif.

3. Verifikasi

Kesimpulan awal yang dikemukakan di awal masih bersifat sementara dan akan berubah bila tidak ditemukan bukti-bukti yang kuat yang mendukung pengumpulan data berikutnya.

Semua data yang telah diperoleh kemudian diolah dan sesudah diolah, maka akan dianalisis dengan pendekatan analisis diskriptif.

\section{HASIL DAN PEMBAHASAN}

Lembaga Amil Zakat YDSF memiliki lima program utama yang salah satunya adalah perduli kemanusiaan dalam program ini memiliki program lebih kecil yang ada didalamnya dinamakan Kelompok Usaha Mandiri (KUM). Program Kelompok Usaha Mandiri (KUM) ini bertujuan untuk memberdayakan masyarakat dengan cara memberikan 
bantuan modal untuk menjalankan usaha mustahiq. Dalam program KUM memiliki dua cakupan wilayah. Pertama, KUM kota yang meliputi wilayah Surabaya dan sekitarnya dalam menyalurkan modal bantuan kepada mustahiq, Lembaga Amil Zakat YDSF memberikan bantuan tersebut kepada kordinator pada masing-masing wilayah, selanjutnya kordinator akan menyerahkan bantuan tersebut kepada masing-masing anggota mustahiq yang bersangkutan. Kedua, KUM Desa ini memiliki cangkupan di kota-kota diluar wilayah Surabaya dalam penyaluran dana modal bantuan dari pihak Lembaga Amil Zakat YDSF memberikan langsung kepada kordinator di setiap kota di wilayah Jawa Timur, selanjutnya akan diteruskan kepada pihak mustahia yang akan menerima bantuan modal tersebut.

Dalam Program Kelompok Usaha Mandiri (KUM) mustahiq yang diberikan bantuan modal dana dari pihak LAZ YDSF akan mendayagunakan dana tersebut untuk meningkatkan usahanya. Penyaluran modal dana ini dilakukan setiap tahun kepada mustahiq, serta mustahiq akan akan mengangur pengembalian dana tersebut setiap bulannya dan biasanya akan disertakan infaq didalamnya itu pun seikhlasnya tanpa diberi patokan berapa akan membayarkan infaq. Program Kelompok Usaha Mandiri dalam penyaluran dana modal bantuan menggunakan akad qardul hasan yaitu pemberian modal kepada mustahiq, tetapi dalam akad ini mustahiq dianjurkan untuk mengembalikan dana tersebut kepada Lembaga Amil Zakat, akan tetapi jika suatu ketika mustahiq tidak dapat mengembalikan dana tersebut dikarenakan suatu sebab, mustahiq tidak diharuskan mengembalikan bantuan tersebut. Serta Lembaga Amil Zakat sendiri tidak berhak meminta kepada mustahiq untuk mengembalikan dana tersebut karena dana tersebut adalah hak milik mustahiq.

Sistem pengembalian dana anggsuran kepada Lembaga Amil Zakat sendiri ini bukan hanya untuk kepentingan Lembaga Amil Zakat saja, tetapi sistem pengembalian dana ini juga bertujuan untuk memandirikan penerima bantuan modal yang awalnya menjadi mustahiq sehingga kedepannya bisa menjadi muzakki. Tidak hanya itu pengembalian dana modal bantuan ini juga bertujuan untuk memberdayakan mustahiq lain yang membutuhkan dana. Sehingga, Dari pengembalian dana modal bantuan untuk mustahiq ini Lembaga Amil Zakat mengelola dana tersebut dan disalurkan kepada mustahiq lain. Diharapkan kedepannya pemberian bantuan ini akan menjadi merata kepada setiap mustahia dan dapat memberdayakan mustahiqmustahiq lain kedepannya.

Sistem pengelolaan harta oleh Lembaga Amil Zakat diarahkan kepada sasaran dalam pengertian yang sifanya lebih luas secara tepat guna, efektif, dan efisien serta dengan pendayagunaan harta zakat serbagunandan produktif. Dimana harta yang terkumpul tidak 
semuanya dibagikan pada zakat yang sifatnya konsumtif, akan tetapi ada sebagian yang diinvestasikan dalam hal yang sifatnya produktif dan nanti keuntungan dari pengelolaan dana zakat tersebut dapat dibagikan kepada golongan ekonomi yang lemah dalam bentuk modal usaha atau dana zakat. Hal ini dilakukan untuk memelihara dari bahaya investasi akibat pendistribusian zakat yang kurang bermanfaat dan zakat untuk kepentingan konsumtif yang tinggi. Dapat disimpulkan bahwa zakat merupakan instrumen untuk mempersempit kesenjangan ekonomi yang tinggi dengan cara memberikan modal kepada mustahia untuk meningkatkan usaha serta pendapatan mereka secara terus-menerus.

$$
\text { Qardhawi }
$$

(2007:

mengungkapkan ekonomi Islam memandang pendapatan merupakan hasil yang diperoleh dari melakukan setiap usaha, baik berupa uang, barang, bahkan hasil yang lainnya. Hasil dari pendapatan dibedakan menjadi dua macam. Pertama, Penghasilan atau pendapatan yang diperoleh dari pekerja yang telah dikerjakan sendiri tanpa bergantung pada orang lain, berkat kecerdasan dan kecakapan merupakan penghasilan secara profesional. Kedua, penghasilan atau pendapatan yang diperoleh dari pekerjaan yang dikerjakan seseorang oleh pihak lain, baik perorangan, perusahaan dan pemerintah dengan memperoleh upah dan gaji yang telah diberikan sebagai hasil dari usaha.

$$
\text { Menurut Puspasari }
$$

menunjukan adanya peningkatan pendapatan mustahiq setelah diberikan dana zakat. Hal ini terbukti berdasarkan hasil wawancara di lapangan dari tiga belas yang diwawancarai semuanya mengalami peningkatan dalam hal pendapatannya. Dapat disimpulkan bahwa bantuan yang diberikan kepada mustahiq dari Lembaga Amil Zakat telah optimal dalam membantu mustahiq. Bantuan modal kerja yang diberikan kepada para mustahiq bertujuan untuk memulai atau mengembangkan usaha mereka, sehingga pendapatan dari hasil usaha (pendapatan kotor) mustahiq dapat meningkat. Proses penyaluran dana dari pihak YDSF melalui program Kelompok Usaha Mandiri (KUM) dilakUkan dengan mempertimbangkan beberapa kriteria. Bantuan modal kerja yang diperoleh melalui program KUM juga dapat memotivasi mustahiq sebagai anggota program yang dapat mendayagunakan dana yang diberikan oleh YDSF dengan baik. Hasil dari pendayagunaan dana infaq produkti untuk mustahiq yang telah berdampak langsung bagi peningkatan pendapatan usaha mustahiq

Dampak pendayagunaan Zakat dan Infaq produktif oleh Yayasan Dana Sosial Al-Falah melalui program Kelompok Usaha Mandiri telah memberdayakan masyarakat yang kurang mampu. Pemberian dana bantuan zakat dan infaa produktif telah memberi dampak pada peningkatan pendapatan baik 
pendapatan dari segi materi maupun dari segi rohani. Berdasarkan hasil wawancara untuk sementara pelatihan dari pihak YDSF belum diadakan tetapi sudah ada pendampingan dan pertemuan rutin antara anggota YDSF bersama perwakilan YDSF dan kordinator wilayah Kediri. Rencana dalam waktu dekat ini akan dibahas dan diadakan pendampingan serta mendirikan koprasi untuk memberdayakan mustahiq. Dengan adanya peningkatan pendapatan mustahiq serta peningkatan rohani hal ini membuktikan bahwa pendayagunaan dana zakat dan infaq produktif oleh mustahiq telah berhasil memberikan dampak yang sangat besar terhadap perkembangan usaha mustahiq.

\section{SIMPULAN}

Pendayagunaan dana zakat dan infaq produktif oleh Lembaga Amil Zakat YDSF di Kediri diberikan dalam bentuk bantuan tambahan modal kepada mustahiq yang memiliki keterbatasan dana dalam mengelola usahanya.

Penerima bantuan dana dari Lembaga Amil Zakat YDSF telah mendayagunakan bantuan tersebut dengan baik. Ini dibuktian dengan meningkatnya pendapatan mustahiq, kelancaran dalam membayar angsuran dan kesanggupan dalam berinfaq. Berdasarkan hasil wawancara dari delapan informan mustahiq tujuh informan mengalami peningkatan, sedangkan hanya ada satu informan yang tidak mengalami peningkatan. Dengan ini, maka dapat dilihat adanya dampak dari pendayagunaan dana zakat dan infaq produktif telah meningkatkan pendapatan mustahiq.

\section{DAFTAR PUSTAKA}

Al Qur'an dan terjemahannya. Departemen Agama Republik Indonesia.

Alwi, Hasan dkk. 2002. Kamus Besar Bahasa Indonesia Edisi Ketiga. Balai Pustaka: Jakarta.

Antonio, M. Syafi'i. 1999. Bank Syaria: Wacana Ulama dan Cendekiawan. Jakarta:Tazkia Institute.

Hasan, M. Ali. 2008. Zakat dan Infaq: Salah Satu Solusi Mengatasi Problema Sosial di Indonesia. Jakarta: Kencana.

Hasan, Sofyan. 1995. Pengantar Hukum Zakat dan Wakaf. Surabaya: AlIkhlas.

Hafidhudin,

Didin. 1998.

PanduanPraktisTentang Zakat, Infaq, Shadaqah. Jakarta: Gemalnsani.

2002. Zakat dalam perekonomian modern. Jakarta: Gema Insani.

http://www.bps.go.id/ ( di akses tanggal 15 juni 2014 ).

Mufraini, arief, 2012. Akuntansi dan manajemen zakat. Mengkomunikasikan Kesadaran dan Mengembangkan Jaringan. Jakarta: Kencana. 
Muhammad. 2011. Ekonomi Mikro Dalam Perspektif Islam. Yogyakarta: BPFE -Yogyakarta.

Pemono, Sjeehul Hadi. 1995. SumberSumber Penggalian Zakat. Jakarta: Pustaka Firdaus.

Qardhawi, Yusuf. 1999. Hukum Zakat (Terjemahan), Jakarta: PT Pustaka Litera Antar Nusa.

Sugiyono. 2012. Metode Penelitian Kuantitatif, Kualitatif, dan R\&D. Bandung: Alfabeta.

Undang-undang No.23 Tahun 2011 tentang pengelolaan zakat. Kitab Undang-Undang Republik Indonesia.

Yin, Robert K. 2009. Studi Kasus, Desain \& Metode Ed 1. Jakarta: Rajawali Press. 